deyatelnosti pravookhanitelnykh organov: problemnye aspekty / A.N.Lepekhin, // Spetsialnaya tekhnika u pravookhoronniy diyalnosti: materially IV mizhnar. nauk.-prakt. konf. ( Kyiv, 26-27 lystopada 2009 roku). K.: Kyivskiy nats. un-t vnutr. Sprav, 2009. S. 8-10.

\title{
I.F. Haraberjush \\ UNAUTHORIZED INVESTIGATIONS (SEARCH) ACTION AS THE OBJECT OF JUDICIAL CONTROL
}

The article deals with unspoken investigative (search) actions as measures that violate constitutional rights and human freedoms and require separate scrutiny. Judicial control is defined as an effective means of safeguarding the constitutional rights and freedoms of the human being, in respect of which the NSRD is conducted using operational and technical means. It is noted that the NSRD are conducted by operational equipment that has not been given due importance and which has not found its place in the judicial review procedure. This, in turn, violates the constitutional rights and guarantees of the victim. There is a justification for the allocation of judicial control in the exercise of the NSRD: preliminary judicial control, which is preventive in nature and aimed at preventing the unlawful and / or unjustified restriction of human rights and freedoms, and the subsequent judicial control, which is carried out after the start of restrictive procedural actions, and pursues the goal of ending unlawful and / or unjustified restrictions on human rights. It is stated that judicial control in the conduct of the NSRD with the use of operational and technical means, has its own peculiarities and requires consideration of the technical factor when granting a permit. The investigating judge should note when agreeing the request that the NSRD may be conducted using only licensed and certified means of silent information.

Keywords: judicial control, unspoken investigators (investigative) actions, pre-trial investigation, operational equipment, software.

Стаття надійшла до редакції 22.10.2019 р.

УДК 341.1(045)

\section{Д. М. Шебаніц}

\section{КОНСТИТУЦЙНІ ЗАСАДИ ПРОТИДІЇ ТЕРОРИЗМУ: ПОРІВНЯЛЬНО- ПРАВОВИЙ АНАЛІЗ}

Стаття присвячена порівняльно-правовому дослідженню конституційних засад протидії тероризму в Україні та зарубіжних державах на сучасному етапі та в історичній ретроспективі.

Ключові слова: тероризм, історичні передумови, конституційне право, протидія тероризму, начіональна антитерористична система.

DOI 10.34079/2226-3047-2019-9-18-69-75

Постановка проблеми та її зв'язок із важливими науковими та практичними завданнями. Міжнародний тероризм у сучасному світі є однією $з$ найбільших загроз не тільки життю людей та економічній інфраструктурі окремих країн, але і викликом для міжнародного правопорядку, найнебезпечнішим посяганням на міжнародний мир та 
безпеку. При цьому останнім часом спостерігається значне поширення методів та форм терористичної боротьби, а також мотивів терористичної діяльності, серед яких слід відзначити політичні, релігійні, етнонаціональні, соціально-економічні.

За такої ситуації засоби протидії міжнародному тероризму $\epsilon$ не досить ефективними, оскільки чинні міжнародно-правові документи та національні антитерористичні інститути спрямовані, в першу чергу, на боротьбу 3 окремими терористичними актами та їх наслідками, а не 3 фундаментальними причинами та умовами міжнародного тероризму як протиправного соціального явища, адже тероризм не існує сам по собі, а його суб'єкти завжди ставлять перед собою певну мету, яка зазвичай не охоплюється безпосереднім виконанням конкретного терористичного злочину.

Таким чином, ефективною протидія тероризму може бути виключно за умови врахування усіх можливих чинників - культурно-духовних, соціально-економічних, політичних, міжнародно-правових, кримінально-правових, військово-поліцейських, організаційних тощо, а це, у свою чергу, потребує формування на базовому рівні конституційно-правових засад протидії тероризму як принципової основи реалізації антитерористичної функції сучасної держави.

Аналіз останніх досліджень і публікацій. В процесі підготовки до написання даної роботи було досліджено національне антитерористичне законодавство України та зарубіжних країн, універсальні та регіональні конвенції з протидії міжнародному тероризму, статистичні матеріали та практику боротьби різних країн 3 тероризмом, наукові праці вітчизняних та зарубіжних вчених 3 міжнародного та кримінального права, а також політології.

Найбільший внесок у дослідження правових питань протидії тероризму, внесли такі вчені, як В. Антипенко, Р. Глен, Дж. Гордон, Д. Кілкаллен, Дж. Маккуен, Дж. Маттіс, Дж. Мацумура, У. Немет, Е. Сімпсон, Р. Уїлкі, Н. Фрейєр, Ф. Гоффман, Е. Тоффлер, Х. Гофмайстер, В. Сліпченко, Д. Ольшанський, О. Картуєва, Г. Хорчем, К. Буртний, Д. Лимонов, В. Бачинін, Ю. Сандалов, М. Крешно, О. Малишева та інші.

Водночас сучасний стан протидії тероризму потребує комплексного аналізу посилення та удосконалення форм та методів антитерористичної діяльності як на міжнародному, так і на національному (у тому числі - конституційному) рівнях функціонування національної антитерористичної системи.

Метою статті $\epsilon$ порівняльно-правовий аналіз конституційних засад протидії тероризму в Україні та зарубіжних державах.

Виклад основного матеріалу. Тероризм належить до числа найнебезпечніших злочинів проти основ конституційного ладу та безпеки держави.

Відповідно до Закону України «Про засади внутрішньої та зовнішньої політики» основними завданнями внутрішньої політики держави у сфері національної безпеки і оборони є своєчасне виявлення, запобігання та нейтралізація реальних і потенційних загроз національним інтересам. Останніми роками суверенітет України випробовувався на міцність під тиском зовнішніх політичних впливів і через уразливість національної економіки, зумовленої кон'юнктурою світового ринку. За цей час накопичилися проблемні питання у сфері соціально-економічних відносин, окреслилися тенденції радикалізації настроїв у суспільстві.

У сучасній вітчизняній юридичній літературі під тероризмом (від лат. terror страх, жах) прийнято розуміти використання насильства чи загрози його застосування щодо окремих осіб, групи осіб або різних об'єктів з метою досягнення політичних, економічних, ідеологічних та інших вигідних терористам результатів [1, с. 36]. 
Разом 3 тим, аналіз ряду робіт вітчизняних авторів по визначенню поняття тероризму свідчить про те, що загальним практично для всіх дослідників при розробці визначення $\epsilon$ прагнення чіткіше розмежувати поняття «терор», «тероризм», «терористичний акт» 3 метою визначити його кваліфікацію як в кримінальному праві, так і в міжнародному, якщо йдеться про таке глобальне сучасне явище, як міжнародний тероризм. Без такої кваліфікації неможливо визначити ефективні шляхи протидії міжнародному тероризму, які охоплюють усі його причини та умови та реально впливають на зменшення інтенсивності терористичної діяльності у світі [2, с. 48].

При цьому серед вчених немає єдиної думки з питання правового визначення поняття тероризму. Одні автори (С. А. Ефірів, А. В. Наумов) вважають, що варто не шукати універсальне визначення тероризму, а слід обмежитися лише деякими його ознаками. На думку інших (А. Є. Жалинський), корисно було б спробувати дати робоче визначення тероризму на правовому рівні. Подібну думку висловлюють і деякі західні дослідники (наприклад, А.-М. Лізен). Інші зарубіжні автори (наприклад, В. Маліссон, С. Маліссон), навпаки, не вважають терор і тероризм поняттями, які ідентифікуються з чітко визначеними фактичними подіями, що відбувається в силу широкого смислового значення цих термінів.

Як вбачається, у широкому юридичному значенні під тероризмом слід розуміти злочинне діяння, яке полягає у застосуванні насильства або в загрозі насильством щодо окремих осіб або групи осіб, що супроводжується залякуванням населення і навмисним створенням обстановки страху, пригніченості, напруженості з метою здійснення впливу на прийняття рішень, вигідних для терористів і відрізняється підвищеною суспільною небезпекою та публічним характером його вчинення. При цьому, цілі терористів можуть бути різними: релігійними, політичними, економічними і т.д. [3, с. 122].

Важливість визначення сутності тероризму, суті цього явища, його структурних елементів як злочинного діяння, обумовлена необхідністю вироблення самостійного поняття тероризму, у тому числі - міжнародного тероризму. Відзначимо, що дослідники проблем тероризму протягом тривалого часу роблять спроби дати точне поняття визначення його сутності. Однак жодне з них не стало загальноприйнятим через складність досліджень в даному напрямку, а також у зв'язку з виникаючими труднощами правозастосовчого характеру. До таких труднощів можна віднести ту обставин, що тероризм як явище досі досліджувався в різних аспектах філософському, політичному, психологічному, правовому і т.д., і кожен з дослідників розглядав це явище зі своєї точки зору, даючи поняттю «тероризм» власну інтерпретацію [4, с. 64].

На нашу думку, під сутністю тероризму слід розуміти сукупність оригінальних ознак, характерних рис і відмітних особливостей, властивих тероризму як соціальнополітичній та правовій категорії, що складають його внутрішній зміст.

Виходячи з подібного розуміння тероризму, як вбачається, у системі державного управління має утвердитися розуміння того, що антитерористична діяльність визначених суб'єктів боротьби з тероризмом є лише складовою державної політики у даній сфері, та може бути комплексний характер і здійснюватися на засадах системної протидії. Вона повинна передбачати не лише організаційно-адміністративні та спеціальні заходи, а й попереджувальну, профілактичну діяльність, що потребує урегулювання широкого кола проблем (від подолання бідності та забезпечення прав і свобод людини і громадянина до виховання політичної та правової культури) [5, с. 42].

Специфіка сучасних проявів міжнародного тероризму актуалізує питання щодо удосконалення нормативно-правової бази, імплементації норм міжнародних нормативних актів у національне законодавство [6, с. 100]. 
Хотілося б підкреслити, що на рівні Свропейського Союзу розпочато роботу 3 підготовки всеосяжної стратегії боротьби з тероризмом та злочинністю, концептуальна основа якої будується на розмежуванні понять «тероризму» та «злочинності». Такий підхід позначатиметься i на визначенні заходів боротьби, що відображатимуть комплексний характер проблеми тероризму. Це і свідчить про зміни на рівні світового співтовариства щодо комплексного сприйняття тероризму і визначення механізмів протидії на системній основі. Зокрема активного використання та законодавчого закріплення набув термін «протидія тероризму», в якому акцентовано увагу на превентивних та регулятивних механізмах запобігання терористичній небезпеці [7, с. 114]. Практика його використання набула поширення і в Україні. Тому закономірно, що забезпечення відповідності норм права суспільним реаліям потребує коригування на законодавчому рівні [8, с. 4].

Постає також питання й щодо необхідності удосконалення нормативно-правової бази у сфері протидії екстремізму. Передусім це стосується правового визначення понять «екстремізм» та «екстремістська діяльність»як правопорушень 3 їх чіткою кваліфікацією, а також створення правових механізмів визнання конкретної структури терористичною або екстремістською, вироблення правових і процесуальних засад формування національного переліку заборонених терористичних та екстремістських організацій. Проте слід зазначити, що дане питання є дискусійним. У ст. 8 Закону України «Про основи національної безпеки» важливим напрямом державної політики 3 питань національної безпеки є запобігання проявам екстремізму. Однак дане поняття не має визначення у національному законодавстві.

Тому, аби уникнути його довільної кваліфікації, необхідно виробити чіткі критерії, за якими те чи інше суспільно-небезпечне явище можна віднести до екстремізму. Можливо, тут не обійтися без грунтовного науково-експертного обговорення у практичному та в теоретичному аспектах [9, с.321].

Вагомим резервом забезпечення етнорелігійної та соціальної стабільності у державі мають стати заходи 3 підтримання міжкультурного та міжконфесійного порозуміння.

У цьому контексті необхідним $є$ посилення координуючої ролі Антитерористичного центру при Службі безпеки України та активізації діяльності Міжрегіональної координаційної комісії щодо об'єднання зусиль міністерств та відомств, громадських організацій, що відповідно до Закону залучаються до протидії тероризму.

До того ж слід підкреслити, що в останній час в українському суспільстві наявна тенденція посиленої уваги до тероризму, передусім з боку засобів масової інформації. До терористичних почали відносити хуліганські дії, кримінальні злочини економічного, соціально-побутового характеру. Це лише збурює суспільну думку і не додає розуміння до вкрай небезпечної сутності явища, що потребує виважених суджень та неупереджених оцінок [10, с. 162].

Для забезпечення єдиного підходу на всіх рівнях держави та суспільства до розуміння сутності тероризму як загрози національній безпеці України необхідно визначити пріоритети держави у питанні подолання тероризму з урахуванням i кримінологічної специфіки, і комплексної соціально-політичної природи даного явища. Йдеться про розроблення концепції протидії тероризму, в якій мають бути визначені основні принципи державної політики, іiї мета, завдання та напрями подальшої оптимізації у середньо- та довгостроковій перспективі [11, с. 17]. 
Іншим важливим аспектом конституційно-правового регулювання протидії тероризму є питання вимушеного обмеження конституційних прав та свобод людини і громадянина під час проведення антитерористичних операцій.

Так, згідно ч. 2 ст. 29 Конституції України, у разі нагальної необхідності запобігти злочинові чи його перепинити уповноважені на те законом органи можуть застосувати тримання особи під вартою як тимчасовий запобіжний захід, обгрунтованість якого протягом сімдесяти двох годин має бути перевірена судом. Затримана особа негайно звільняється, якщо протягом сімдесяти двох годин з моменту затримання їй не вручено вмотивованого рішення суду про тримання під вартою. Усупереч цьому, законодавством про антитерористичну операцію передбачено превентивне затримання громадян без вмотивованого рішення суду на строк до 30 діб [12].

Крім того, ч. 1 ст. 41 Конституції України гарантовано право безперешкодно володіти, користуватися і розпоряджатися своєю власністю. Однак особам, які залучені до антитерористичної операції, надано право проводити особистий догляд громадян, огляд речей, що при них знаходяться, транспортних засобів та речей, які ними перевозяться [12].

Виникає закономірне питання про конституційність обмежень прав і свобод, які можуть вводитися на час проведення антитерористичної операції, оскільки за ч. 2 ст. 8 Конституції України вона має найвищу юридичну силу.

Так, можливість обмеження конституційних прав і свобод врегульовано ст. 64 Конституції України. Цією статтею передбачено, що конституційні права і свободи людини і громадянина не можуть бути обмежені, крім випадків, передбачених Конституцією України. Таких випадки лише два: воєнний стан та надзвичайний стан. Інших підстав для обмеження конституційних прав і свобод немає.

Як нами 3'ясовано, антитерористична операція не підпадає під поняття воєнного або надзвичайного станів. Таким чином, звуження конституційних прав громадян під час проведення антитерористичної операції заборонено самою Конституцією України.

У той же час, масовий антидержавний характер та істотні суспільно-небезпечні наслідки діяльності терористичних організацій зумовлюють практичну необхідність у введенні обмежень прав і свобод людини та громадянина. Зокрема, слід визнати, що обмеження прав у випадку вчинення масових терористичних актів, $є$ необхідними i виправданими.

Наразі існують два основні шляхи адаптації (усунення колізій) Основного закону України та законодавства про антитерористичну операцію:

1) внесення змін до Конституції України, зокрема, до ч. 2 ст. 64 Конституції України слід додати, що обмеження конституційних прав і свобод також тимчасово допускаються під час проведення антитерористичної операції. Однак цей спосіб $є$ процедурно складним (внесення змін до Конституції України здійснюється за спеціальним ускладненим порядком - розділ XIII Конституції України) й може свідчити про звуження змісту та обсягу існуючих прав і свобод (забороняється ч. 3 ст. 22 Конституції України);

2) визначення антитерористичної операції як виду військового стану.

Як вбачається, запропоновані підходи допоможуть уникнути вищевказаних юридичних перепон, але встановлять для антитерористичної операції додаткові регламентні вимоги щодо порядку введення, функціонування, припинення тощо.

Крім того, при використанні цього шляху антитерористичної операції матиме ті самі обмеження, що й військовий стан. Зокрема, превентивне затримання особи на строк понад 72 години (ч. 3 ст. 14 Закону України «Про боротьбу з тероризмом») все одно буде неприпустимим, оскільки воно обмежує право на особисту недоторканість 
(ст. 29 Конституції України), а останнє заборонено навіть в умовах воєнного або надзвичайного стану (ч. 2 ст. 64 Конституції України).

Висновки. Отже, протидія тероризму є комплексною системою, яка включає юридичні, політичні, соціально-економічні, військові та поліцейські заходи 3 метою усунення не тільки наслідків, але і глибинних причин тероризму як соціального явища. Виключно у подібній сукупності проблема протидії тероризму може бути вирішена якісно та остаточно у сучасному сповненому конфліктів світі. При цьому протидія міжнародному тероризму базується на сукупності міжнародно-правових документів як імперативних, так і тих, що відносяться до т. з. «м'якого права», тобто рекомендаційних, морально-політичних джерел (зокрема, саме такими джерелами $\epsilon$, наприклад, резолюції Генеральної Асамблеї ООН), а правову базу співробітництва держав у боротьбі зі злочинами тероризму в даний час складають універсальні конвенції, основним об’єктом уваги котрих, $є$ не тероризм як уособлення глобального терористичного конфлікту 3 визначеними протиборчими сторонами $\mathrm{i}$ засобами боротьби, а окремі терористичні акти (або акти тероризму), що становить серйозну міжнародно-правову проблему.

3 іншого боку, ефективна протидія тероризму є можливою за умови одночасного створення належної національної антитерористичної системи, базові засади функціонування якої слід врегулювати на найвищому, конституційно-правовому рівні.

\section{Список використаної літератури}

1. Беглова Н. С. Терроризм: поиск решения проблемы. США: Экономика. Политика. Идеология. 1991. № 1. С. 36-45.; Beglova N. S. Terrorizm: poisk resheniya problemy. SShA: Ekonomika. Politika. Ideologiya. 1991. № 1. S. 36-45.

2. Авдеев Ю. И. Основные тенденции современного терроризма. Современный терроризм: состояние и перспективы. Москва : Эдиториал УРСС, 2000. С. 44-62.; Avdeev Yu. I. Osnovnye tendentsii sovremennogo terrorizma. Sovremennyy terrorizm: sostoyanie i perspektivy. Moskva : Editorial URSS, 2000. S. 44-62.

3. Павлинов А. Международный терроризм: совершенствование организационноправовых форм борьбы с ним. Уголов. право. 2002. № 4. C. 121-123.; Pavlinov A. Mezhdunarodnyy terrorizm: sovershenstvovanie organizatsionno-pravovykh form borby $\mathrm{s}$ nim. Ugolov. pravo. 2002. № 4. S. 121-123.

4. Остроухов В. В. Філософські проблеми дослідження насилля і терору. Київ : Укр. Центр духов. культури, 2000. 246 с.; Ostroukhov V. V. Filosofski problemy doslidzhennia nasyllia i teroru. Kyiv : Ukr. Tsentr dukhov. kultury, 2000. $246 \mathrm{~s}$.

5. Талалаев А. И. Право международных договоров. Москва: Междунар. отношения, 1980. 312 с.; Talalaev A. I. Pravo mezhdunarodnykh dogovorov. Moskva: Mezhdunar. otnosheniya, 1980. $312 \mathrm{s.}$

6. Левин Д. Б. Проблема ответственности в науке международного права. Изд. АН CCСР. Отд-ние экономики и права. 1946. № 2. C. 99-155.; Levin D. B. Problema otvetstvennosti v nauke mezhdunarodnogo prava. Izd. AN SSSR. Otd-nie ekonomiki i prava. 1946. № 2. S. 99-155.

7. Левин Д. Б. Ответственность государств в современном международном праве. Москва : Междунар. отношения, 1966. 152 с.; Levin D. B. Otvetstvennost gosudarstv v sovremennom mezhdunarodnom prave. Moskva : Mezhdunar. otnosheniya, 1966. $152 \mathrm{~s}$.

8. Лекарев С. В. Разведка мирового сообщества. Независимое военное обозрение. 2001. 5 окт. C. 4-5.; Lekarev S. V. Razvedka mirovogo soobshchestva. Nezavisimoe voennoe obozrenie. 2001. 5 okt. S. 4-5. 
9. Лунеев В. В. Преступность XX века. Мировые, региональные и российские тенденции: мировой криминологический анализ. Ин-т гос-ва и права РАН. Москва. Норма, 1999. 516 c.; Luneev V. V. Prestupnost XX veka. Mirovye, regionalnye i rossiyskie tendentsii: mirovoy kriminologicheskiy analiz. In-t gos-va i prava RAN. Moskva. Norma, 1999. $516 \mathrm{~s}$.

10. Ляхов Е. Г. Проблемы сотрудничества государств в борьбе с международным терроризмом. Москва: Междунар. отношения, 1979. 168 с.; Lyakhov Ye. G. Problemy sotrudnichestva gosudarstv v borbe s mezhdunarodnym terrorizmom. Moskva: Mezhdunar. otnosheniya, 1979. $168 \mathrm{~s}$.

11. Международная борьба с терроризмом (правовые аспекты): научноаналитический обзор. Москва: ИНИОН, 1988. 42 с.; Mezhdunarodnaya borba s terrorizmom (pravovye aspekty): nauchno-analiticheskiy obzor. Moskva: INION, 1988. 42s.

12. Конституція України від 28 червня 1996 p. URL: http://www.kmu.gov.ua/document/ 110977042/Constitution_eng.doc; Konstytutsiia Ukrainy vid 28 chervnia 1996 r. URL: http://www.kmu.gov.ua/document/ 110977042/Constitution_eng.doc.

\section{D.M. Shebanic \\ THE CONSTITUTIONAL PRINCIPLES OF COUNTERACTION TO TERRORISM: COMPARATIVE LEGAL ANALYSIS}

The article is devoted to the comparative legal study of the constitutional foundations of counteracting terrorism in Ukraine and foreign states at the present stage and in historical retrospect.

Key words: terrorism, historical background, constitutional law, counteraction to terrorism, national antiterrorist system.

Стаття надійшла до редакції 24.10.2019 р.

УДК 354.07:351.176: [07:316.658](477)

\section{П. О. Яковлєв}

\section{КОМПЕТЕНЦІЯ ВИЩИХ ОРГАНІВ ДЕРЖАВНОЇ ВЛАДИ УКРАЇНИ У СФЕРІ ЗАБЕЗПЕЧЕННЯ ІНФОРМАЦИЙНОЇ БЕЗПЕКИ}

Стаття присвячена висвітленню особливостей компетениії вищих органів державного управління України у сфері забезпечення інформаційної безпеки держави. Зазначено, щуо основні ризики і загрози інформачійній безпечі Украйни детермінуються значними темпами розвитку інформатизації $і$ інформаційної структури суспільства. Обгрунтовано, що забезпечення інформаційної безпеки держави $є$ пріорітетним завданням діяльності всієї системи органів державного управління України $i$ передбачає визначення інновачійних підходів до формування системи захисту та розвитку інформаційного простору в умовах глобалізації та вільного обігу інформації.

Запропоновано авторське визначення категорії "компетенція вищих органів державної влади Украӥни у сфері забезпечення інформаційної безпеки», зміст якої передбачає систему визначених у нормативно-правових акта владних повноважень, які застосовуються з метою виявлення $i$ попередження загроз інформаційному суверенітету Украӥни, захисту національного інформаційного простору від здійснення 